\title{
Passenger Loyalty Analysis: Case Study on Indonesian Commuter Trains
}

\author{
Nazwirman ${ }^{1 *}$, Zainal Zawir Simon ${ }^{2}$ \\ Yarsi University, Jakarta, Indonesia

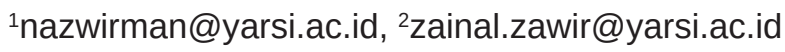 \\ ${ }^{*}$ Coresponden author
}

\begin{abstract}
This study was aim is to analyze and describe passenger loyalty influenced by the desired service quality performance and satisfaction at PT Kereta Commuter Indonesia (KCI). A sample consisting of 198 respondents was selected based on the particular criteria. The analysis method used was Satistical Package for Social Science (SPSS) version 24 and Analysis of Moment Structure (AMOS) version 22. The results obtained from three hypotheses revealed that the performance of service quality influenced significantly on satisfaction. The service quality performance influenced loyalty significantly. Satisfaction significantly influences loyalty. The customer satisfaction mediated the significance influence of service quality dimensions toward loyalty of the customers. Important dimension in this study were that KCI officers disposed to help if needed; passengers had a positive attitude; and KCI was the main choice rated by respondents. This study provided theoretical and managerial contribution for marketing service field. In terms of theoretical implications, each dimension of the performance of service quality could show different levels of the effect toward consumer behavior and was able to offer significant contribution for a company.
\end{abstract}

Keywords: PT Kereta Commuter Indonesia, loyalty, performance of service quality, satisfaction

\begin{abstract}
Abstrak
Penelitian ini bertujuan untuk menganalisis dan mendeskripsikan loyalitas penumpang yang dipengaruhi oleh kinerja kualitas pelayanan yang diinginkan dan kepuasan pada PT Kereta Commuter Indonesia (KCI). Sampel yang terdiri dari 198 responden dipilih berdasarkan kriteria tertentu. Metode analisis yang digunakan adalah Paket Satistik Ilmu Sosial (SPSS) versi 24 dan Analisis Struktur Momen (AMOS) versi 22. Hasil yang diperoleh dari tiga hipotesis menunjukkan bahwa kinerja kualitas pelayanan berpengaruh signifikan terhadap kepuasan. Kinerja kualitas pelayanan mempengaruhi loyalitas secara signifikan. Kepuasan berpengaruh signifikan terhadap loyalitas. Kepuasan pelanggan memediasi pengaruh signifikansi dimensi kualitas layanan terhadap loyalitas pelanggan. Dimensi penting dalam penelitian ini adalah petugas KCI bersedia membantu jika diperlukan; penumpang memiliki sikap positif; dan KCI adalah pilihan utama yang dinilai oleh responden. Studi ini memberikan kontribusi teoritis dan manajerial untuk bidang jasa pemasaran. Dari sisi implikasi teoritis, setiap dimensi kinerja kualitas layanan dapat menunjukkan tingkat pengaruhnya yang berbeda terhadap perilaku konsumen dan mampu memberikan kontribusi yang signifikan bagi suatu perusahaan.
\end{abstract}

Kata kunci: PT Kereta Commuter Indonesia, loyalty, performance of service quality, satisfaction

\section{Cara Mengutip:}

Nazwirman, Simon, Z. Z. (2020). Passenger Loyalty Analysis: Case Study on Indonesian Commuter Trains. Esensi: Jurnal Bisnis dan Manajemen. Vol.10 (1) :121-134. DOI: http://doi.org/10.15408/ess.v10i1.12556 


\section{INTRODUCTION}

Rail transportation creates new challenges for railway operators because of the competitive environment (Zeybek, 2018). Generally current business challenges is not only trying to attract new customers, but also trying to adopt strategies to maintain and promote loyalty to build long-term relationships with customers (Akbar, et al., 2013). The most significant is preventing loss and retaining customers so that the company's market share and profits can be guaranteed (Osman et al., 2009). Customer loyalty presents a paradox that appears as an attitude-based phenomenon and can be significantly influenced by customer relationship management (Mark et al., 2003). Customer loyalty start from their trust service quality; positive and beneficial attitudes that are manifested repeatedly and the stability of consumer buying behavior (Chow. 2014; Castro et al., 2004). Service quality contributes significantly to customer satisfaction and loyalty and is attractive to profitability (Seth \& Deshmukh, 2005). Providing customers with better services leads to higher purchase frequencies and directly impacts the organization's ability to improve, because organizations are able to find what customers want and need (Kumar, 2017). Therefore increasing company profitability can be realized through efficiency and effectiveness in service delivery (Chang \& Chen, 1998).

As part of transportation facilities, railway are generally used because of their ability to transport large amounts of cargo and passengers. In the Jakarta and its surrounding areas, many people use PT Kereta Commuter Indonesia (KCI) service for their daily activities. KCI has been serving routes in the Jakarta and its surrounding areas, such as Bogor, Bekasi, Lebak and Tangerang (http://www.krl.co.id/). KCI continues to work hard to meet the target of serving up to 1.2 million passengers per day with a fleet strength of up to 1,450 units in 2019. Until June 2018, it is noted that the average number of KCI users reached 1,001,438 users per day on working days, with 1,154,080 user as the a record for the highest number of users which is served in one day (https://www. cnbcindonesia.com/news/).

This study focuses on service quality performance, because it can make a significant contribution to customer satisfaction and loyalty (Seth and Desmukh, 2005). It is a known fact about service delivery based on the values that customers want can play an extraordinary role in ensuring customer satisfaction and loyalty. Previous study conducted by Lin (2005) shows that service can satisfy satisfied customers and satisfied customers tend to be loyal customers (Oliver 1999). This study's purpose is examining the relationship between service quality performance, satisfaction and customer loyalty in KCI. This competitive environment forces companies to pay more attention to the quality of their service, that is highly desirable and make greater efforts to ensure customer satisfaction and loyalty.

This study differs from previous studies that examined KCI passengers using and testing the effect of perceived service quality performance variables, satisfaction variables as mediation and loyalty variables. Previous studies conducted on tourist passengers and local train passengers in the country of Sri Lanka (Perera, 2016), fast train passengers in Taiwan, (Chou et al, 2014) and other tranportations (Lai \& Chen, 2011; Carreira et al, 2013; Mahmoud \& Hine, 2016). 


\section{Service Quality Performance}

The concept of services is centered on the efforts to meeting the needs and desires of consumers and the accuracy to offset expectations (Lovelock \& Wirtz, 2007). Quality of service is a function of the relationship between basic expectations and experiences as well as customer impressions before and after receiving service. Service quality can be evaluated based on the delivery process and the results of the services delivered (Fitzsimmons, 2008). When evaluating service quality, customers tend to judge based on certain subjective criteria formed before experiencing new services. Expectations of services provided are largely influenced by prior experience as a customer.

Quality of service is the performance of the service that the customer truly feels. The quality of services based on performance will better reflect the quality of services (Ranaweera \& Sigala, 2015; Cronin \& Taylor, 1994). The empirical work of Parasuraman et al., (1998) service quality starts with 22 items used, then becomes five dimensions, namely: Tangible, Resposibility, Reliability, Insurance, and Emphaty. Their study results show that service performance is the best model in service quality where the service-based scale focuses on conceptualization and measurement of quality as an attitude. Initially the quality of service was proposed by Gronroos (1990).

In a competitive environment where service quality important and is a critical factor that determines the success of an organization through the analysis of problems encountered, meetings with customers, follow-ups that carried out, and a series of report making, processes, and performance (Jain \& Gupta, 2004; Zeithaml et al., 2006; Parasuraman et al., 1988). Many researchers believe that the customer opinions about quality are based on long-term evaluation after receiving the services of company, while customer satisfaction is a short-term emotional response to particular service experiences (Seyed Javadein, 2010).

\section{Customer satisfaction}

The main principle of customer satisfaction is accordance of their expectations before the purchase and opinions formed about performance after the purchase is made (Kundu \& Datta 2015). This behavior is called the expectation-disconfirmation paradigm. Customers are satisfied if expectations are met and dissatisfied if the product or service fails to meet expectations (Caruana 2002; Narteh 2015; Yuksel \& Yuksel 2001).

Satisfaction is a feeling of pleasure or disappointment someone, which comes from the comparison between their impression of the performance or results of product and service with their expectations (Kotler, 2003). Jamal and Naser, (2002) report customer satisfaction is a consumer feeling or attitude towards the service or product used. Consumer satisfaction is also attitude of consumers as whole after acquiring and using product or services and is a choice from evaluation results of their purchasing and consuming experiences (Mowen \& Minor, 2001; Szymanski \& Henar, 2001).

In this study, customer satisfaction is measured by four items, including the results of the service felt by the customer as a whole until the satisfied reached, improves the impression and always has a positive attitude towards KCI. 


\section{Customer loyalty}

Loyalty refers to a strong commitment to reuse products or services in the future. Loyalty is also related to the word choice, where customers are very likely to choose certain products that lead to loyalty (Lin \& Wang, 2006). The customer loyalty indicators used in this study are making regular purchases, referring to others, and refusing other services (Griffin, 2005).

Loyalty programs are designed to increase customer satisfaction and commitment and to provide benefits or perceived value to members as a token of appreciation for their loyalty to the organization. Additionally Bolton et al., 2000) report that when customers are involved in a loyalty program, the perceived benefits they receive will lead to loyalty.

Quality of service plays an important role in creating customer satisfaction. The relationship between service quality performance and customer satisfaction is well established in the service marketing literature (Antony et.al. 2004; Ladhari 2009; Sivadas and BakerPrewitt 2000). Therefore, providing a high level of service quality to achieve the highest customer satisfaction is considered the most important goal for many businesses to gain customer loyalty (Reichheld \& Sasser 1990; Zeithaml et al., 2009). Specifically, customer satisfaction is suggested for mediating variables between service quality and customer loyalty (Caruana 2002).

\section{Hypothesis}

Caruana (2002) found that customer satisfaction plays the role of mediator, how service quality affects customer loyalty. Customer satisfaction is characterized as a customer evaluation of a product or service that has needs and expectations (Alan et al., 2012). Service quality performance and satisfaction have certain things in the same way, but satisfaction is generally a broader mind, (Alan et al., 2012). Research Zeithaml et al., (2006) reported that the quality of costs and goods can affect customer satisfaction. Other researchers report that service quality performance has an effect on the satisfaction of transport users (Coelho \& Henseler, 2012; Rida et al., 2012; Nyongesa \& Hendry, 2014; Tirinda et al., 2013). Therefore this research hypothesis:

$\mathrm{H}_{1}$ : There is a significant influence on Service Quality Performance (SP) on Satisfaction (CS)

Cronin et al., (2000) describe the results of the study found was no directly effect between service quality on customer loyalty through customer satisfaction in the services of the six companies studied. There are those that directly affect service quality Customer Loyalty (Sunghyup Sean Hyun (2010) \& Carrillat AF, et.al (2009), Ravichandran, (2010), Pollack (2009), Ziaul Hoq, (2009), there also states that no quality of service directly affects customer loyalty (Bastos (2008).

Associated with the service industry Anderson \& Fornell (2000) state that there is a relationship between service quality and loyalty. In the service industry, the point comes from the Service Quality factor (Lin, 2007). Research (Chow et al., 2014; Jianjun \& Canming, 2011) states that there is an effect of service quality on loyalty. Therefore this research hypothesis:

$\mathrm{H}_{2}$ : There is a significant influence on Service Quality Performance (SP) on Loyalty (LY). 
Customer satisfaction also turns out to be a concern to improve service companies. Wen et al., (2005) state that customer satisfaction can increase customer purchase intensity. The creation of an optimal level of customer satisfaction encourages the creation of loyalty. Customer loyalty has an important meaning in a company. The longer the customer is loyal to the product or service, the greater the profit gained by a company (Griffin, 2005).

Hallowell (1996) reports that satisfaction has a positive influence on customer loyalty. The same thing was expressed (Wang et al., 2014; Wen et al., 2005; Wong \& Sohal, 2003), but increased in satisfaction did not always result in an increase in loyalty at the same level. Satisfaction has no significant effect on customer loyalty (Sahadevs \& Keyoor P (2008).

According to previous studies, showed the customer satisfaction will gradually lead to feelings of loyalty (Brunner et al., 2008). Loyal customers play an important role in increasing profitability and can improve the company's image. Potential customers are factors that contribute to the company through support and recommendations to relatives, friends and others. According to the research conducted so far, it has been proven and ensures that customer satisfaction will gradually lead to feelings of loyalty. Loyal customers play an important role in increasing profitability and improving the image of the organization. 90 percent of the customers who are dissatisfied with their company never return to use the products or services provided by the organization. Furthermore, each customer who is dissatisfied will say their problem to at least 9 others, 13 percent of whom are then retold the problem to more than 20 other people (Seyed et al., 2011; Gures et al., 2014; Kavoosi \& Saghaei, 2009). Therefore this research hypothesis:

$\mathrm{H}_{3}$ : There is a significant effect of Satisfaction (CS) on Loyalty (LY).

Research (Chow et al., 2014; Jianjun \& Canming, 2011) states that there is an effect of service quality on satisfaction and loyalty. Based on the above theory, the variables were identified, then a research model can be made between Service Quality Performance, Loyalty through Satisfaction (Figure 1):

Figure 1. Research Model

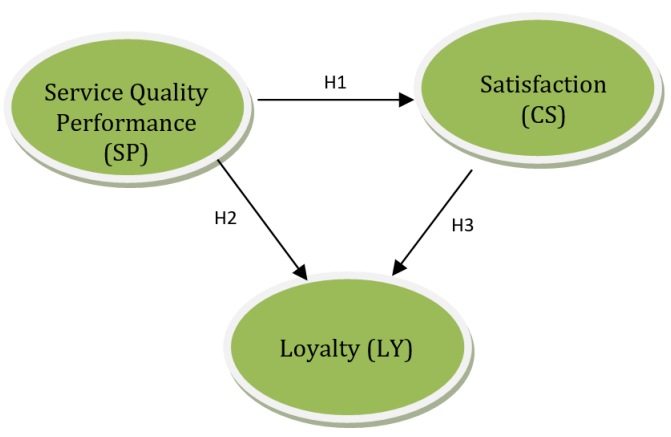

This research involves calculating the equation of the exogenous variable service quality performance (SP) of 22 indicators. Endogenous variable loyalty (LY) with 4 indicators and intervening variable customer satisfaction (CS) with 4 indicators. This study allows expanding the findings of previous studies that reveal the mediating role of customer satisfaction from service quality performance variables and customer loyalty (Caruana, 2002). 


\section{METHOD}

This type of research uses quantitative methods systematically on some parts and the fundamental relationships between empirical observations and mathematical expressions (Creswell, 2009; McMillan and Schumacher, 2006). This research using a causal design is to find out the impact of another variable based on the logic of hypothesis testing, which ultimately produces inductive conclusions (Sekaran, 2013; Malhorta, 2012).

Samples used are passengers who use KCI services; they are selected based on screening (non probabilistic). The sample size is adjusted by statistical analysis of Structural Equation Modeling (SEM). The sample was chosen based on the researchers' assessment that the respondent was the best party to become the research sample (Sekaran, 2013; Hair 2010).

The type of data collected is primary data collected through questionnaires, interviews and observations. Secondary data was collected from related documents, such as journals and the internet. To provide a description of the variable characters, we used a frequency table that shows the average number (mean). This analysis uses SPSS (Satistical Package for Social Science) software version 24 (Santoso, 2014). Second, structural equation modeling (SEM) analysis with AMOS (Analysis of Moment Structure) Version 22 (Ghazali, 2017) is used to verify several paths or relationships between research constructs.

\section{RESULTS AND DISCUSSION}

The sampled of 200 respondents, 198 were analyzed and met the criteria. The results of the descriptive analysis are divided into gender, age, education, monthly income and needs using KCI (Table 1).

Table 1: Descriptive Analysis Based on Respondent Characteristics

\begin{tabular}{llcc}
\hline & Characteristics & Amount & Percent \\
\hline Gender & Male & 111 & 56,1 \\
UsiaAge & Women & 87 & 43,9 \\
& $<20$ Years & 21 & 10,6 \\
& 20-30 Years & 67 & 33,8 \\
& 31-40 Years & 45 & 22,7 \\
& 41-50 t Years & 40 & 20,2 \\
& 51-60 Years & 18 & 9,1 \\
& $>60$ Years & 7 & 3,5 \\
& Middle School & 12 & 6,1 \\
& High School & 100 & 50,5 \\
& Academy & 21 & 10,6 \\
& Bachelor & 51 & 25,8 \\
& Postgraduate & 14 & 7,1 \\
\hline & Privat Employees & 143 & 72,2 \\
& Civil servants & 14 & 7,1 \\
\hline
\end{tabular}




\begin{tabular}{llcc}
\hline \multicolumn{1}{c}{ Characteristics } & Amount & Percent \\
\hline & Entrepreneur & 7 & 3,5 \\
Student & 30 & 15,2 \\
& Pention & 4 & 2 \\
Income/Month & <Rp 3 Million & 40 & 20,2 \\
& Rp 3 - Rp 4,999 Million & 79 & 39,9 \\
Rp 5 - Rp 7,9999 Million & 65 & 32,8 \\
& Rp 8 - Rp 10 Million & 7 & 3,5 \\
>Rp 10 Million & 7 & 3,5 \\
Work & 128 & 64,6 \\
Business & 17 & 8,6 \\
School & 34 & 17,2 \\
Other & 19 & 9,6 \\
\hline Total & 198 & $\mathbf{1 0 0}$ \\
\hline
\end{tabular}

Source: Results of data processing with SPSS V. 24

From Table 1, it can be seen that the characteristics of KCI user respondents based on gender 111 of the are men people or 56.1 percent and 87 people are women or 43.9 percent. This is very possible because there are more male passengers who work outside the home (Perera, 2016; Chou et al., 2014). The number of respondents aged 20 to 30 years is 67 people or 33.8 percent, the highest number, and it is very considering the mobility at this age (Carreira et al., 2013). Respondents with high school degree are 100 people or $50.5 \%$, the largest compared to other education degree. Respondents who work Employees are 143 people or 72.2 percent, the most dominant compared to other professions. Respondents who earn from 3 - 4,999 million are 79 people or 39.9 percent. Respondents who used KCI for the purposes of working are 128 people or 64.6 percent and the most dominant compared to other purpose (Chou et al., 2014; Perera, 2016).

\section{VALIDITY AND RELIABILITY TEST}

The value is valid if $r_{\text {count }}$ is greater than $r$ table. For sample (n) 198 (n-2) $r_{\text {table }}$ is 0.139. Of the 22 indicators of Service Quality Performance (SP), 4 indicators of Satisfaction (CS), and 4 indicators of Loyalty (LY) all are valid because the value of Corrected Item-Total Correlation $\left(r_{\text {count }}>r_{\text {table }}\right.$. 0.139).

To the test of the reliability of the measurement model, the test, is carried out using a construct reliability (CR) measurement and variant extract (VE). In Table 2, it shows that all the latent variable indicators have a Standard Loading Factor (SLF) value $\geq 0.50$. All latent variables have a $t$-value $\geq 1.96$. This result also shows that the SP variable indicator reflects the latent variable that is the SP variable. The CS variable indicator reflects the latent variable with CS. Indicators for the latent variable LY also have an SLF value $\geq 0.50$ and $t$-value $\geq 1.96$. These results indicate that the indicators of the latent variable $\mathrm{LY}$ reflect the LY variable. All indicators examined are valid. 
Table 2: Measurement Indicator Results

\begin{tabular}{|c|c|c|c|}
\hline & SLF & Error & $t$-value \\
\hline $\mathrm{sp} 20 \leftarrow \mathrm{SP}$ & 0,913 & 0,19 & 11,84 \\
\hline $\mathrm{sp} 19 \leftarrow \mathrm{SP}$ & 0,918 & 0,15 & 11,91 \\
\hline $\mathrm{sp} 18 \leftarrow \mathrm{SP}$ & 0,829 & 0,30 & 9,52 \\
\hline $\mathrm{sp} 17 \leftarrow \mathrm{SP}$ & 0,749 & 0,47 & 5,95 \\
\hline $\mathrm{sp} 16 \leftarrow \mathrm{SP}$ & 0,540 & 0,76 & 5,95 \\
\hline sp15 $\leftarrow$ SP & 0,465 & 0,65 & 4,93 \\
\hline $\mathrm{sp} 14 \leftarrow \mathrm{SP}$ & 0,454 & 0,62 & 5,13 \\
\hline $\mathrm{sp} 13 \leftarrow \mathrm{SP}$ & 0,909 & 0,13 & 11,29 \\
\hline $\mathrm{sp} 12 \leftarrow \mathrm{SP}$ & 0,913 & 0,17 & 11,29 \\
\hline $\mathrm{sp} 11 \leftarrow \mathrm{SP}$ & 0,891 & 0,30 & 9,52 \\
\hline $\mathrm{sp} 10 \leftarrow \mathrm{SP}$ & 0,779 & 0,45 & 6,68 \\
\hline $\mathrm{sp} 9 \leftarrow \mathrm{SP}$ & 0,889 & 0,27 & 7,33 \\
\hline $\mathrm{sp} 8 \leftarrow \mathrm{SP}$ & 0,899 & 0,27 & 7,33 \\
\hline $\mathrm{sp} 7 \leftarrow \mathrm{SP}$ & 0,896 & 0,28 & 7,33 \\
\hline $\mathrm{sp} 6 \leftarrow \mathrm{SP}$ & 0,529 & 0,72 & 5,95 \\
\hline $\mathrm{sp} 5 \leftarrow \mathrm{SP}$ & 0,531 & 0,67 & 5,33 \\
\hline $\mathrm{sp} 4 \leftarrow \mathrm{SP}$ & 0,779 & 0,45 & 6,68 \\
\hline $\mathrm{sp} 3 \leftarrow \mathrm{SP}$ & 0,889 & 0,27 & 7,33 \\
\hline $\mathrm{sp} 2 \leftarrow \mathrm{SP}$ & 0,899 & 0,27 & 7,33 \\
\hline $\mathrm{sp} 1 \leftarrow \mathrm{SP}$ & 0,896 & 0,29 & 7,33 \\
\hline $\mathrm{sp} 21 \leftarrow \mathrm{SP}$ & 0,529 & 0,72 & 5,95 \\
\hline $\mathrm{sp} 22 \leftarrow \mathrm{SP}$ & 0,531 & 0,71 & 5,85 \\
\hline $\mathrm{CS} 1 \leftarrow \mathrm{CS}$ & 0,747 & 0,48 & 5,95 \\
\hline $\mathrm{CS} 2 \leftarrow \mathrm{CS}$ & 0,842 & 0,30 & 9,41 \\
\hline $\mathrm{CS} 3 \leftarrow \mathrm{CS}$ & 0,816 & 0,32 & 9,41 \\
\hline $\mathrm{CS} 4 \leftarrow \mathrm{CS}$ & 0,765 & 0,52 & 7,75 \\
\hline$L Y 4 \leftarrow L Y$ & 0,811 & 0,31 & 9,45 \\
\hline$L Y 3 \leftarrow L Y$ & 0,701 & 0,50 & 7,75 \\
\hline $\mathrm{LY} 2 \leftarrow \mathrm{LY}$ & 0,854 & 0,34 & 9,41 \\
\hline$L Y 1 \leftarrow L Y$ & 0,693 & 0,60 & 5,16 \\
\hline
\end{tabular}

Source: Results of data processing with AMOS 
From the estimation results provided, we can calculate the CR and VE values of each latent variable, the results of which are given in table 3 , below:

Table 3: Reliability of Measurement Model Results

\begin{tabular}{|c|c|c|c|}
\hline \multirow{2}{*}{ Variabel } & \multicolumn{2}{|c|}{ Reliability } & \multirow{2}{*}{ Explanation } \\
\hline & $C R \geq 0,70$ & VE $\geq 0,50$ & \\
\hline $\mathrm{SP}$ & 0,89 & 0,77 & Reliabel \\
\hline CS & 0,84 & 0,67 & Reliabel \\
\hline LY & 0,87 & 0,71 & Reliabel \\
\hline
\end{tabular}

The reliability value of the measurement model can be seen from the CR and VE values, and it shows that the measurement model in this study is reliable for measuring SP, CS, and LY. This can be seen from the CR and VE values of the research variables, with CR values $>0.70$ and VE values $>0.50$, so the measurement model in this study is reliable.

To see if the model matches the available data, a test will be carried out to test the overall fit of model with the data. The following is a list of criteria or Goodness of Fit (GOF) models used to test the model thoroughly. The test for the full feasibility of the SEM model:

Table 4: Estimates of the Statistical Test Model

\begin{tabular}{|c|c|c|c|}
\hline Goodness of Fit & Cut-off Value & Estimated Results & $\begin{array}{l}\text { Results of the } \\
\text { model }\end{array}$ \\
\hline $\begin{array}{l}\text { Chi-Square } \\
\text { P-value } \\
\text { Normed Chi-Square }\end{array}$ & $\begin{array}{l}\text { The smaller better } \\
\text { p-value } \geq \alpha \text { selected } \\
\text { Chi-Square/df, lower limit : } 0.1 \\
\text { Upper limit: } 2.0 ; 3.0 ; 5.0\end{array}$ & $\begin{array}{l}x^{2}=817 ; d f=146 \\
p=0,00<0,05 \\
383.21 / 146=2.62\end{array}$ & Poor \\
\hline PGFI & PGFI > 0.6 & 0.65 & Marginal Fit \\
\hline $\begin{array}{l}\text { RMSEA } \\
\text { P (close fit) }\end{array}$ & $\begin{array}{l}\text { RMSEA } \leq 0.08 \text { (good fit) } \\
\text { RMSEA }<0.05 \text { (close fit) }\end{array}$ & $\begin{array}{l}0.78 \\
P=0.000<0.05\end{array}$ & Good Fit \\
\hline ECVI & $\begin{array}{l}\mathrm{ECVI}<\mathrm{ECVI} \text { for Saturated dan } \\
\text { Independence }\end{array}$ & $\begin{array}{l}\mathrm{M}^{*}=4.76 \\
\mathrm{~S}^{*}=3.84 \\
\mathrm{I}^{*}=14.08\end{array}$ & Good Fit \\
\hline AIC & $\mathrm{AIC}<\mathrm{S}$ AIC dan I AIC & $\begin{array}{l}\mathrm{M}^{*}=471.21 \\
\mathrm{~S}^{*}=380 \\
\mathrm{I}^{*}=1393.77\end{array}$ & Good Fit \\
\hline CAIC & CAIC $<$ S CAIC dan I CAIC & $\begin{array}{l}M^{*}=629.84 \\
S^{*}=1064.98 \\
I^{*}=1462.27\end{array}$ & Good Fit \\
\hline $\mathrm{NFI}$ & $\begin{array}{l}\mathrm{NFI} \geq 0.90 \text { (good fit) } \\
0.80 \leq \mathrm{NFI} \leq 0.90 \text { (marginal fit) }\end{array}$ & 0.82 & Marginal Fit \\
\hline NNFI & $\begin{array}{l}\text { NNFI } \geq 0.90 \text { (good fit) } \\
0.80 \leq N N F I \leq 0.90 \text { (marginal fit) }\end{array}$ & 0.80 & Marginal Fit \\
\hline $\mathrm{CFI}$ & $\begin{array}{l}\mathrm{CFI} \geq 0.90 \text { (good fit) } \\
0.80 \leq \mathrm{CFI} \leq 0.90 \text { (marginal fit) }\end{array}$ & 0.85 & Marginal Fit \\
\hline IFI & $\begin{array}{l}\mathrm{IFI} \geq 0.90 \text { (good fit) } \\
0.80 \leq \mathrm{IFI} \leq 0.90 \text { (marginal fit) }\end{array}$ & 0.81 & Marginal Fit \\
\hline
\end{tabular}




\begin{tabular}{llll}
\hline RFI & RFI $\geq 0.90$ (good fit) & Marginal Fit \\
& $0.80 \leq \mathrm{RFI} \leq 0.90$ (marginal fit) & 0.81 & Poor \\
\hline $\mathrm{CN}$ & $\mathrm{CN} \geq 200$ & 50.47 & Good Fit \\
\hline $\mathrm{RMR}$ & $\mathrm{RMR} \leq 0.05$ (good fit) & 0.043 & Poor \\
\hline $\mathrm{GFI}$ & $\mathrm{GFI} \geq 0.90$ (good fit) & & \\
\hline AGFI & $0.80 \leq \mathrm{GFI} \leq 0.90$ (marginal fit) & 0.76 & Marginal Fit \\
& $\begin{array}{l}\text { AGFI } \geq 0.90 \text { (good fit) } \\
0.80 \leq \mathrm{AGFI} \leq 0.90 \text { (marginal fit) }\end{array}$ & 0.83 & \\
\hline
\end{tabular}

Source: Results of data processing with AMOS

The overall test results of the model indicated that there are 2 (two) results that are not good (poor), it can be concluded that the hypothesized model is good enough to be used for testing hypotheses.

Table 5: The Structure Equation Modeling

\begin{tabular}{ccc}
\hline Model & T- $_{\text {count }}$ & Probabilistic $(\boldsymbol{\rho})$ \\
\hline SP to CS & 4,274 & 0,003 \\
SP to LY & 9,338 & 0,000 \\
CS to LY & 3,536 & 0,004 \\
\hline
\end{tabular}

\section{EFFECT OF SP ON CS}

The variable SP to CS has a $\mathrm{t}_{\text {count }}$ of 4.274 greater than $\mathrm{t}_{\text {table }} 1.9718\left(\mathrm{t}_{\text {count }}>\mathrm{t}_{\text {table }}\right)$ and a probability value of 0.003 is smaller than the significance level of $0.05(\rho<0.05)$. So the results show that SP has a significant positive effect on CS.

For KCI passengers service quality performance they feel is on "good" level, so they are satisfied. This is indicated by the representative feature of the train, a lot of choices of schedules (routes), the service of officers both on the train and outside of it is quite good so that passengers feel satisfied with the service performance. In order to increase passengers satisfication, KCI has to pay more attention to a number of things, such as schedule precision so that passenger arrivals can be predicted. This research is also in line with Coelho and Henseler, (2012); Rida et al., (2012); Nyongesa \& Hendry, (2014); Tirinda et al., (2013).

\section{EFFECT OF SP ON CS}

The SP variable to LY has a $\mathrm{t}_{\text {count }}$ of 9.3338 greater than $\mathrm{t}_{\text {table }} 1.9718\left(\mathrm{t}_{\text {count }}>\mathrm{t}_{\text {table }}\right)$ and a probability value of 0.000 is smaller than the significance level of $0.05(\rho<0.05)$. So $0,000<0.05$, the results in this study indicate that the SP has a significant positive effect on LY.

KCI's service quality performance shows that passengers are quite loyal. This is indicated by a fairly representative indicator, where KCI provides very clear information on routes, relatively timely train departures, and helpful officers who are able to meet the needs of passengers during the trip. Passenger loyalty will be further enhanced by their willingness to tell and inform KCI to colleagues and family. This study was also in Anderson and Fornell (2000); Lin, (2007); Chow et al., (2014); Jianjun \& Canming, (2011). 


\section{EFFECT OF SP ON CS}

The SC variable to LY has a $\mathrm{t}_{\text {count }}$ of 3.536 greater than $\mathrm{t}_{\text {table }} 1.9718\left(\mathrm{t}-{ }_{\text {count }}>\mathrm{t}_{\text {table }}\right)$ and a probability value of 0.008 is smaller than the significance level of $0.05(\rho<0.05)$. It can be concluded that $0.004<0.05$, the results in this study indicate that CS has a significant positive effect on LY.

Generally KCI passengers are satisfied will impact on their loyalty. This is indicated by the positive attitude of the passengers. Passenger prefers to use this mode compared to other modes of transportation, especially for travelling within the city. Their good impression has increased for KCI. Some users become loyal by always using this mode of transportation for their purposes while simultaneously inviting their colleagues to do same. This study was also in line with with Wang et al., (2014); Wen et al., (2005); Wong \& Sohal, (2003).

The results regarding the hypothesis are seen in all (Table 5). show the structure and results of the model analysis (Figure 2):

Figure 2. Structure and results of the model analysis

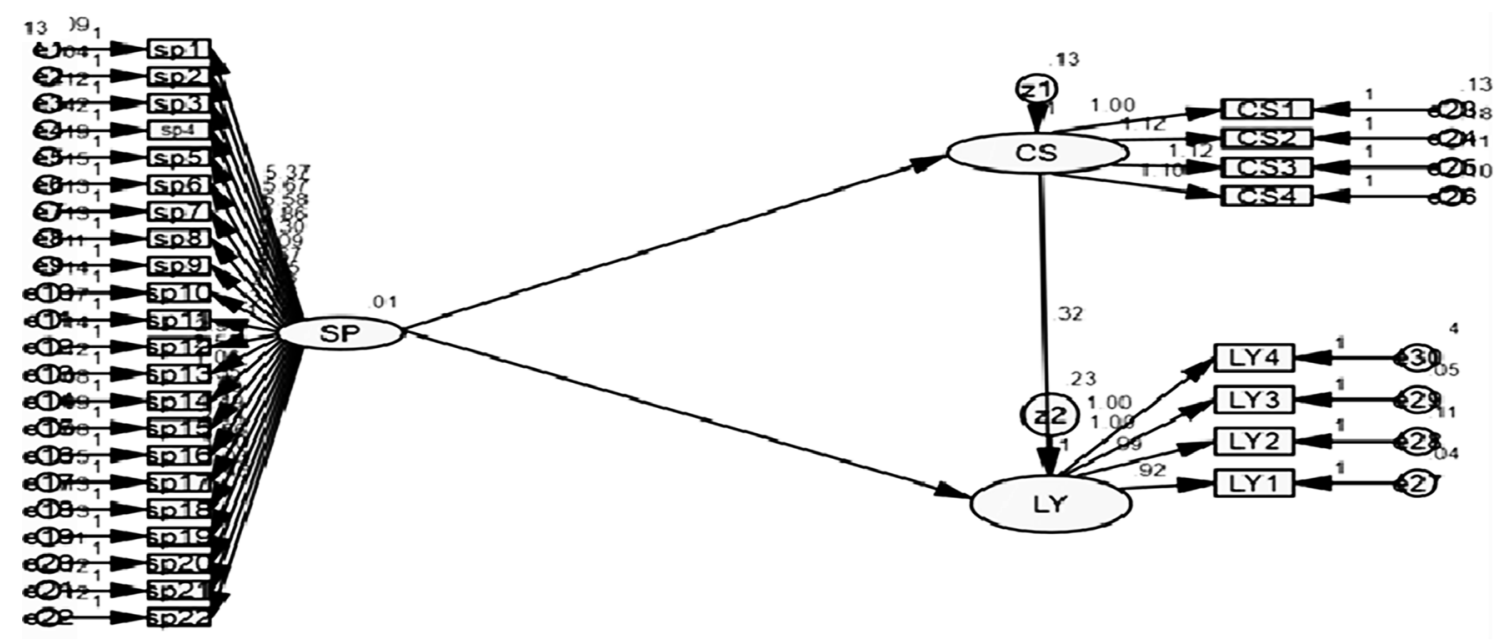

From Figure 2 the structure and results of the SEM model can be shown the results of direct and indirect path calculations from the variables studied (Table 6).

Table 6: Results of Direct / Indirect Path Calculations

\begin{tabular}{cccc}
\hline Variabel & Direct Effect & Indirect Effect & Total Effect \\
\hline $\mathrm{SP} \rightarrow \mathrm{CS}$ & 0,42 & & \\
$\mathrm{SP} \rightarrow \mathrm{LY}$ & 0,30 & & \\
$\mathrm{CS} \rightarrow \mathrm{LY}$ & 0,32 & & \\
$\mathrm{LY} \rightarrow \mathrm{SP} * \mathrm{CS}$ & & $0,42 * 0,32=0,13$ & $0,30+0,13=0,43$ \\
\hline
\end{tabular}

Source: Results of data processing with AMOS

The direct effect of SP on CS was 0.42. The direct effect of SP on LY was 0.30. The direct effect of CS on LY was 0.32. While the indirect effect of SP on LY through CS is 0.13 
and the total effect is 0.43 , which means that CS is able to mediate SP on LY, because the total value is greater than the value of the direct efffect (Samuel \& Nadya, 2009; Darsono, 2008).

\section{CONCLUSION}

In the Jakarta and surrounding areas, some people use the services of PT Kereta Commuter Indonesia (KCI) for activities. KCI serves routes in and around DKI Jakarta, Bogor City, Bogor Regency, Bekasi City, Lebak Regency, Tangerang City and South Tangerang City.

The competitive environment forces $\mathrm{KCI}$ to pay attention to the quality of service that customers really want and make greater efforts to ensure satisfaction and loyalty. The company continues to meet its targets in serving passengers with the strength of its fleet. Research focuses on service quality performance variables that can make a significant contribution to the satisfaction and loyalty variables. As well as testing the three service quality performance variables, loyalty variables and satisfaction variables as intermediary variables.

Based on the results obtained from the three hypotheses answered, it can be concluded that the performance of service quality significantly influenced customer satisfaction. Service quality performance significantly influenced customer loyalty. Customer satisfaction significantly influenced customer loyalty. Customer satisfaction mediates the significant influence of service quality dimensions toward loyalty of the customer.

The indicator supports passenger loyalty where the train feature is representative enough to be used, has a lot of departure schedules. The clerk is quite helpful if needed. Passengers always have a positive attitude. KCI is the first choice for users compared to other public transport modes. Indicators that are of considerable concern to the company are the lack of train cars and departure schedules

This study makes theoretical and managerial contributions to the field of service marketing. In terms of theoretical implications, the present study shows that each dimension of service quality performance can show different levels of influence on consumer behavior in the case of KCI. In addition, the results of this study indicate that service quality performance must be examined at the dimensions, not at the aggregate level, because each dimension may have different interests or relevance.

\section{REFERENCES}

Akbar, Ali Esmaeli, Baran Aryee Manesh, \& Ebrahim Golshan. (2013). Service Quality, Customer Satisfaction and Customer Loyaltyin RAJA Rail Transportation Company. International Research Journal of Applied and Basic Sciences. Vol. 5 (3): 347-352

Alan, W., Valarie A., Z., Mary Jo, B., \& Dwayne D., G. (2012). Services Marketing:Integrating Customer Focus Across the Firm (2 ed.). Europe: McGraw-Hill Education.

Anderson, E. W., \& Fornell, C. (2000). Faoundations of the American Customer Satisfaction Index. Total Quality Management. Vol. 11(7): 869-882.

Antony, J., Antony, F. J., \& Ghosh, S. ( 2004). Evaluating service quality in a UK hotel chain: a case study. International Journal of Contemporary Hospitality Management, 16(6): 380-384

Bastos, J A.R., \& Gallego, P.M (2008). Pharmacies Customer Satisfaction and Loyalty: A Framework Analysis. Journal of Marketing. Universidad de Salamanca 
Bloemer, J., De Ruyter, K. \& Peeters, P. (1998). Investigating drivers of bank loyalty: the complex relationship between image, service quality and satisfaction. International Journal of Bank Marketing. Vol. 16 (7): 276-286

Bolton, R. N., Kannan, P. K., \& Bramlett, M. (2000). Implications for Loyalty Program Membership and Service Experiences for Customer Retention and Value. Journal of Academy of Marketing Science. Vol. (28/28): 95-108

Brunner, T. A., Stöcklin, M. \& Opwis, K. (2008). Satisfaction, image and loyalty: New versus experienced customers. European Journal of Marketing. Vol. 42(9/10): 1095-1105.

Carreira, R., Patrício, L., Jorge, R. N., Magee, C., \& Hommes, Q. V. E. (2013). Towards a Holistic Approach to The Travel Experience: a Qualitative Study of Bus Transportation. Transport Policy. Vol. 25: 233-243.

Caruana, A. (2002). Service loyalty: The effects of service quality and the mediating role of customer satisfaction. European journal of marketing, Vol. 36(7/8): 811-828.

Castro CB, Armario EM, \& Ruiz DM. (2004). The influence of employee organizational citizenship behavior on customer loyalty. International Journal of Service Industry Management. Vol. 15(1): 27-53.

Chang T, \& Chen S. (1998). Market orientation, service quality and business profitability: a conceptual model and empirical evidence. Journal of Service Marketing. Vol. 12(4): 246-264

Chow, Pin-Fenn, Chin-Shan Lu \& Yu-Hern Chang. (2014). Effects of service quality and customer satisfaction on customer loyalty in high-speed rail services in Taiwan. Journal Transportmetrica A: Transport Science . Vol. 10(10): 917-945

Coelho, P. S. \& Henseler, J. (2012). Creating customer loyalty through service customization. European Journal of Marketing. Vol. 46(3/4): 331-356.

Creswell, J. (2009). Research design: Qualitative, quantitative, and mixed methodsapproaches. 3rd edition. Thousand Oaks: Sage.

Cronin, J.J \& Taylor, S. A. (1994). "SERVPERF Versus SERVQUAL: Reconciling Performance Based and Percep-tion Minus Expections Measurement of Service Quality", Journal of Marketing. Vol. (58): 125-131

Cronin, J.J., Brady, M.K., \& Hult, G.T.M. (2000). Assessing the effects of quality, value and customer satisfaction on consumer behavioural intentions in service environments. $J$. Retail. Vol. 76(2): 193-218

Darsono, Licen Indahwati. (2008, September 6). Hubungan perceived service quality dan loyalitas: peran trust dan satisfaction sebagai mediator. The 2nd National Conference UKWMS Surabaya

Fitzsimmons, JA, MJ. (2008). Service management operation, strategy and information technology. Tr: Aarabi S.M, Izadi D. $2^{\text {th }}$ ed. Daftar pajoohesh haye farhangi. Tehran

Ghozali, Imam (2017). Model Persamaan Struktural Konsep dan Aplikasi dengan Program AMOS 24.0 Update Bayesian SEM. Undip Press

Griffin, Jill. (2005). Customer Loyalty-How to Earn it,How to keep it. Graw Hill,Kentucky

Gronroos, Christian. (1990). Service Management and Marketing: Managing the Moment of Truth in Service Competition. Massachusetts: Lexington.

Gures, Nuriye, Seda Arslan, \& Sevil Yucel Tun. (2014). Customer Expectation, Satisfaction and Loyalty Relationship in Turkish Airline Industry. International Journal of Marketing Studies. Vol. 6(1): 1729-1742. 
Hallowell, Roger. (1996). The Relationships Of Customer Satisfaction, Customer Loyalty, And Profitability: An Empirical Study. International Journal of Service Industry Management, Vol. 7(4): 27-42.

Hair, J., W. Black, B. Babin, \& R. Anderson. (2010). Multivariate data analysis, $7^{\text {th }}$ ed., Prentice Hall. Hoffman, K., \& Bateson, J. (2006). Services marketing: Concepts, strategies and cases (3 ed.). Mason, OH: Thomson /South-Western

https://www.cnbcindonesia.com/news/20190310144514-4-59728/tahun-ini-krl-commuterline-bidik-12-penumpang-hari, accessed July 8, 2019.

http://www.krl.co.id/, accessed July 8, 2019.

Jain, S. K., \& Gupta, G. (2004). Measuring Service Quality: SERVQUAL vs. SERVPERF Scales. The Journal for Decision Makers. Vol. 29(4): 25-37. https://doi.org/10.1177/0256090920040203

Jamal A, Naser K. (2002). Customer satisfaction and retail banking: an assesment of some of the key antecedents of customer satisfaction in retail banking. International Journal of Bank Marketing. Vol. 20(4): 146-160.

Jianjun C, \& Canming C. 2011. An empirical analysis of the relationship among the service quality, customer satisfaction and loyalty of high speed railway based on structural equation model. Canadian Social Science. Vol. 7(4): 67-73.

Juran, Joseph M. (1998). Juran's quality handbook. 5th edition. New York: McGraw-Hill.

Kavoosi MR, \& Saghaei A. (2009). Customer satisfaction evaluation techniques. $1^{\text {th }}$ ed. Ameh. Tehran

Keh, H. T., \& Lee, Y. H. (2006). Do Reward Programs Build Loyalty for Services? The Moderating Effect of Satisfaction on Type and Timing or Rewards. Journal of Retailing. Vol. 82(2): 127-136

Kotler, Philip. (2003). Marketing Management. International Edition. New Jersey: Prentice-Hall

Kumar, Atul. (2017). Effect of service quality on customer loyalty and the mediating role of customer satisfaction: an empirical investigation for the telecom service industry. Journal of Management Research and Analysis. Vol. 4(4):159-166.

Kundu, S. \& Datta, S.K., (2015). Impact of trust on the relationship of e-service quality and customer satisfaction. EuroMed Journal of Business. Vol. 10(1): 21-46.

Ladhari, R. (2009). Service quality, emotional satisfaction and behavior intentions: a study on hotel industry. Managing Service Quality, 19, (3): 308-331

Lai, W. T., \& Chen, C. F. (2011). Behavioral Intentions of Public Transit Passengers -The Roles of Service Quality, Perceived Value, Satisfaction and Involvement. Transport Policy. Vol. 18(2): 318-325.

Lin, W. B. (2007). An empirical of service quality model from the viewpoint of manament. Expert Systems with Applications. Vol. 32: 364 - 375.

Lin H, \& Wang Y. (2006). An examination of the determinants of customer loyalty in mobile commerce contexts. Information \& Management. Vol. 43(3): 271-282.

Lin, C. (2005). Relationship between Guest Perceptions of Service Quality and Customer Loyalty in the Hotel Industry in South Florida, Lynn University.

Lovelock, Christopher, \& Jochen Wirtz. (2007). Service Marketing: People, Tecnology. Strategy $6^{\text {th }}$ Edition. Pearson Education Inc. 
Malhorta, Naresh K. (2012). Basic marketing research: integration of social media. 4th ed. New Jersey: Upper Saddle River

Mark D Uncle, Grahame Dowling, \& Kathy Hammond. (2003). Customer Loyalty and Customer Loyalty Programs. Journal of Consumer Marketing. Vol. 20(4): 294-316.

McMillan J \& Schumacher S. (2006). Research in Education: Evidence-Based Inquiry. 6th ed. Boston: Pearson.

Mahmoud Moataz \& Julian Hine. (2016). Measuring the influence of bus service quality on the perception of users. J Transportation Planning and Technology . Vol 39(3):1-16

Mowen, John,.C, \& Michael Minor. (2001). Customer Behavior. Fifth Edition. New Jersey:PrenticeHall.

Narteh, B. (2015). Perceived service quality and satisfaction of self-service technology. International Journal of Quality \& Reliability Management. Vol. 32(4): 361-380.

Nyongesa, David Murambi \& Henry M. Bwisa. (2014). Service Quality and Customer Satisfaction in Public Transport Sector of Kenya: A Survey of Shuttle Travelers in Kitale Terminus. International Journal of Academic Research in Business and Social Sciences. Vol. 4(9): 402-412

Ok, Sokchan \& Thammanoon Hengsadeekul. (2018). Customer Satisfaction on Service Quality of Bus Transport: A Survey of Passengers from Phnom Penh to Poipet in Cambodia. Journal of Social Science Studies. Vol. 5, (2), 114-131

Oliver, R. L. (1999). Whence Consumer Loyalty? Journal of Marketing. 63(1): 33.

Osman H, Hemmington N, \& Bowie D. (2009). A transactional approach to customer loyalty in the hotel industy. International Journal of Contemporary Hospitality Management. Vol. 21(3): 239-250.

Parasuraman, A., Berry, Leonard L., \& Zeithaml, Valarie A. 1988. A Concepttual Model of Service Quality and Its Implication for Future Research. Journal of Marketing, 41-50.

Perera R. A. S. A. (2016). The Impact Of Railway Transport Service Quality On Passengers' Satisfaction; A Study Based On Kandy Railway Station. Conference: Proceeding of International Conference on Contemporary Management (ICCM), 678-692

Pollack B. (2009), Linking the Hierarchical Service Quality Model to Customer Satisfaction and Loyalty. Journal of Service Marketing. Vol. 23(1): 42-50.

Ranaweera, C. \& Sigala, M. (2015). From service quality to service theory and practice, Journal of Service Theory and Practice. Vol. 25(1): 2-9. Doi.org/10.1108/JSTP-112014-0248

Ravichandran, (2010), Influence of Service Quality on Banking Customers Behavioural Intentions. International Journal of Economics and Finance. Vol. 2(4),

Reichheld, F. F., \& Sasser, W. E. (1990). Zero defection: Quality comes to services. Harvard Business Review. Vol. 86(5): 105-111.

Richheld F. (1996). The loyalty effect, the hidden force behind growth, profits and lasting value. Cambridge. MA: Harvard Business School Press.

Rida, K., Hummayoun, N., Sana, E., Faiza, M., \& Taha, B. (2012). Service Quality And Customer Satisfaction In Public Transport Sector Of Pakistan: An Empirical Study. International Journal of Economics and Management Sciences. Vol. 1(9): 24-30.

Sahadev. Sunil, \& Keyoor Purani. (2008). Modelling the Consequences of service Quality. Marketing Intelligence \& Planning. Emerald Group Publishing Limited. Vol. 26(6): 605-620. 
Semuel, Hatame \& Nadya Wijaya. (2009). Service Quality, Perceive Value, Satisfaction, Trust, Dan Loyalty Pada PT. Kereta Api Indonesia Menurut Penilaian Pelanggan Surabaya. Jurnal Manajemen Pemasaran, 4(1), 23-37

Santoso, Singgih. (2014). SPSS 22 from Essential to Expert Skill + CD. Jakarta: Elek Media Komputindo.

Sekaran, Uma. 2013. Research Methods for Business: A Skill Building Approach, $6^{\text {th }}$ Edition, New York, USA: John Wiley \& Son, Inc.

Seth N, \& Deshmukh SG. (2005). Service quality models: a review. International Journal of Quality \& Reliability Management. Vol. 22 (9): 913-949.

Seyed Javadein R, Khanlari A, \& Estiri M. (2011). A model for evaluating the effects of dervice quality on customer loyalty in the sport services. Olympic.18(4/52):41-54.

Shahin A, \& Teimouri H. (2008). Customer loyalty, concept \& models. $1^{\text {th }}$ ed. Jahad daneshgahi vahed Isfahan. Isfahan.

Sivadass, E. and Baker-Prewitt, J. L., (2000). An Examination of the Relationship Between Service Quality, Customer Satisfaction and Store Loyalty, International Journal of Retail \& Distribution Management. Vol. 28(2): 73-82

Sunghyup Sean Hyun (2010). Predictorys of Relationship Quality and Loyalty in the Chain Restaurant Industry. Cornell Hospitaliry Quarterly. Ithaca. Vol. 51(2): 251

Szymanski, D.M. \& Henar d, D.H. (2001).Customer Satisfacti On: A Meta Analysis of the Empirical Evidence". Journal of Academic of Marketing Science. Vol. 29(1): 16-35.

Wang, Ming-Yuan; Li, Wei-Chin; Chou, Mei-Ju; Huang, \& Chien-Jung. (2014). Nostalgia, Perceived Value, Satisfaction, And Loyalty of Cruise Travel. International Journal of Organizational Innovation. Vol. 6(4): 184-191.

Wen, C.H., Lan, L.W. \& Cheng, H.L. (2005). Structural equation modelling to determine passenger loyalty toward intercity bus services. Journal of the Transportation Research Board . Vol. 19(27): 249 - 255

Wen, C.H., Lan, L.W. \& Cheng, H.L. (2005). Structural equation modelling to determine passenger loyalty toward intercity bus services ". Journal of the Transportation Research Board , Vol. 19(27): 249 - 255

Wong, A. \& Sohal, A. (2003). Service quality and customer loyalty perspectives on two levels of retail relationships. The Journal of Services Marketing. Vol. 17(4/5), 495-511.

Yuksel, A. \& Yuksel, F, (2001). Measurement and management issues in customer satisfaction research: Review, critique and research agenda: Part one. Journal of Travel and Tourism Marketing. Vol. 10(4): 47-80. Doi.org/10.1300/J073v10n04_03

Zeithaml, V. A., Mary Jo Bitner \& Dwayne D. Gremler. (2006). Service Marketing: Integrating Customer Focus Across The Firm. $5^{\text {th }}$ Edition, The McGraw Hill Companies Inc.

Zeithaml, V. A., Bitner, M. J., and Gremler, D. D. (2009). Services Marketing: Integrating Customer Focus across the Firm. 5th ed. Singapore: McGraw-Hill and Irwin

Zeybek, Hulya. (2018). Customer segmentation strategy for rail freight market: The case of Turkish State Railways. Research in Transportation Business \& Management. 28, 45-53

Ziaul Hoq, \& Muslim Amin (2009), The Role of Customer Satisfaction to Enhance Customer Loyalty. Eurasian Journal of Business and Economics. Vol. 2(4): 139-154. 